\title{
Evaluation of Trace Metal Concentrations in Tuticorin Coastal Water near Thermal Power Plant
}

\author{
Sugirtha P. Kumar ${ }^{1}$, Clara Jeyageetha .J \\ ${ }^{1}$ Department of Chemistry, Women’s Christian College, Nagercoil - 629 001, Tamil Nadu, India \\ ${ }^{2}$ Department of Chemistry, A.P.C Mahalaxmi College for Women, Tuticorin - 628 001, Tamil Nadu, India
}

\begin{abstract}
Water is the most important chemical compound for the perpetuation of life on this planet. Owing to the rapid industrialization on one side and exploding population on the other, seawater gets polluted. Seawater pollutant is a chemical substance present in it at the excessive levels capable of causing harm to living organisms. The Tuticorin Thermal Power station (TTPS) utilized 18,000 tons/day of coal and contributed an important pollutant of fly ash. TTPS discharged effluent caused ecological perturbation depletion of oxygen and showed poor species diversity. A study was conducted to investigate the impact of fly ash dumpsite of Tuticorin coastal area from thermal power plant. Water samples were collected from three different stations fixed in and around $5 \mathrm{~km}$ of ash dumpsite of power plant in monthly intervals during the year of July 2014 to June 2015. Trace elements of Fe, Cu, Pb and Cd were found high in ash dumpsite. The results of the present study recommended the proper steps to be taken to prevent and minimize the adverse environmental impacts include aggressive marketing to promote industrial use of ash.
\end{abstract}

Keywords: Thermal power station, fly ash, Tuticorin coastal area, water samples, trace elements

\section{Introduction}

Aquatic ecosystems have been affected by various types of contaminations around the globe in the recent few years. Heavy metals are one of the most common pollutants which have severely deteriorated the aquatic ecosystems [1] due to their toxicity, abundance, persistence, and subsequent bioaccumulation. Their release in aquatic ecosystem is triggered by both natural and anthropogenic processes [2]. A thermal power plant generates large amounts of fly ash which contain toxic metals [3]. The disposal of coal fly ash in ash pond subjects these metal rich materials to conditions that results in further sequestration of the metals or to their release to the environment [4]. There are various interactions that occur when fly ash and water come together, which include precipitation/dissolution, complex formation, adsorption/desorption and redox reactions, which are bound to control the mechanisms of mobilization of toxic metals in the water [5]. Fly ash is generally captured from the chimneys of coal-fired power plants. Earlier until 1991 the fly ash was dumped into sea by Tuticorin Thermal power plant. After the CRZ notification by the Ministry of Environment and Forests, dumping of fly ash into Tuticorin coastal waters has been stopped.

Ganesan and Kannan, [6] showed higher concentration of Fe and $\mathrm{Mn}$ in the sea water, sediment and algae in the vicinity of Tuticorin Port. Palanichamy and Rajendran, [7] indicated high concentration of $\mathrm{Cd}$ and $\mathrm{Pb}$ in the bottom waters than the surface waters of Tuticorin. Present study was carried out in the vicinity of a Tuticorin thermal power plant in coastal water to evaluate the trace metals concentrations in the earlier ash dumped site.

\subsection{Description of study area}

Tuticorin Bay is situated in the South east coast of India in the Gulf of Mannar along the Tamil Nadu coast. The area under investigation gets great interest because of its presence in the industrial belt. In addition, a major harbour, thermal power plant, heavy water plant, and fishing harbor are considered sources of pressure on the marine environment in this region.

Tuticorin Thermal Power Station (TTPS) is located about 2 $\mathrm{km}$ to the east of Tuticorin Port and the northern boundary of the complex is on the brim of the intertidal area of the Tuticorin Bay (Lat. 08 46! 20" N; Long. 78 10! 46" E). TTPS is a coal - fired thermal power station and hence large amount of fly ash (6,000 Metric Tonnes per day) is generated during the process. Tuticorin Thermal Power Station functioning since 1976 and is generating $1050 \mathrm{MW}$ of electricity. About 17,000 metric tons of coals are used as fuel for the power generation per day. Presently the hot water effluent generated by cooling the condenser has pumped directly into the Bay. In this present investigation the study area is located near the earlier fly ash dumpsite in Tuticorin coastal water and this also contains the water outfall from the coolant. So this area received high temperature of water. Two stations (station 1 and 2) were fixed at distance of 500 meter and $2 \mathrm{~km}$ from the outfall of TTPS and station 3 was fixed at a distance of $3 \mathrm{~km}$ from the outfall of TTPS and is considered as control site shown in Fig .1

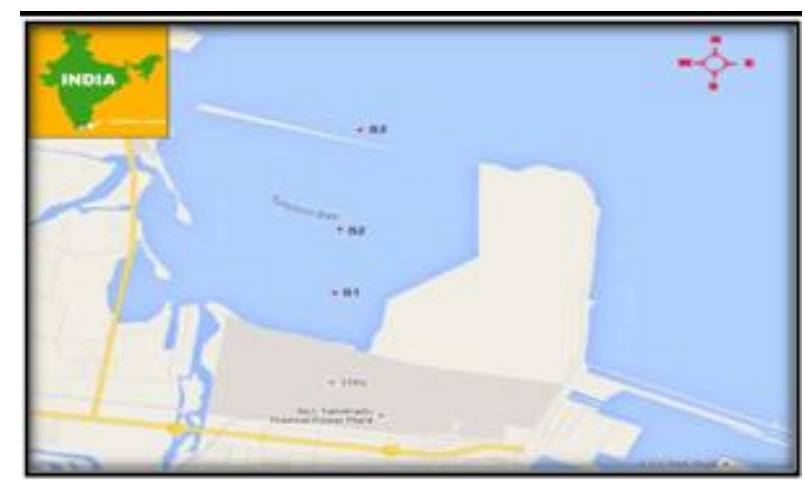

Figure 1: Map showing the study area (Tuticorin Bay) with 3 stations

Volume 5 Issue 6, June 2016 www.ijsr.net 


\section{International Journal of Science and Research (IJSR) \\ ISSN (Online): 2319-7064}

Index Copernicus Value (2013): 6.14 | Impact Factor (2015): 6.391

Station 1 : 500 meters away from water outfall of power plant (Earlier ash dumpsite) (N 08 46' 48.3' \& E 078 10' 76.3"). This area do not containing any biological system due to the water with high temperature from outfall of thermal power plant and the presence of fly ash.

Station $2: 2 \mathrm{~km}$ away from the water outfall of power plant. (N $08^{\circ} 47^{\prime} 32.0^{\prime \prime} \& \mathrm{E} 078^{\circ} 10^{\prime} 80.3$ "). This area also do not containing any biological system. The impact of outfall water from power plant and fly ash extents over in this area too.

Station 3 (Control site) : $3 \mathrm{~km}$ away from the station 2 (N $08^{\circ} 47^{\prime} 85.5^{\prime \prime} \&$ E $078^{\circ} 10^{\prime} 65.3$ "). This area contains biological system like coral reef and sea grass bed, and considered as control site.

\subsection{Collection of water samples}

The water samples were collected from 3 stations every month for a period of one year from July 2014 to June 2015. The surface water samples were collected in a pre-cleaned plastic containers using nitric acid, bottom water samples were collected using Meyer's water sampler, and samples were transferred into pre-cleaned plastic containers and analyzed various metals.

\section{Materials and Methods}

To study the impact of fly ash on marine environment, the heavy metals in seawater were analyzed by Atomic absorption spectroscopy.

\section{Heavy metals in seawater}

The filtered water samples were pre-concentrated with APDC (Ammonium pyrrolidine di carbomate) - MIBK (Methyl isobutyl ketone) extraction procedure as described by Brooks et al., [8] and aspirated to Atomic Absorption Spectrophotometer (AAS; Elico-SD164India). Filtered water (1L) was divided into two $500 \mathrm{~mL}$ aliquots and the $\mathrm{pH}$ was adjusted to $\mathrm{pH} 4 \pm 0.1$ by careful drop-wise addition of $50 \%$ $\mathrm{HNO}_{3}$. The heavy metals were pre-concentrated and separated from the bulk matrix by complexation with APDC and extraction into MIBK. The organic layer containing the metal chelates were collected and back extracted with $50 \% \mathrm{HNO}_{3}$, and diluted with metal free double distilled water to a minimum quantity $(25 \mathrm{ml})$.

\section{Results and Discussion}

The water samples were analyzed for trace elements and the results were shown in table 1 .

\subsection{Iron}

The mean value of iron in surface water ranged between $106.3 \pm 33.24$ to $219.89 \pm 88.4 \mu \mathrm{g} / \mathrm{L}$ (Fig .2). The maximum value was recorded in station 1 (Table .1) and minimum value was recorded in station 3. The highest value of 345.24 $\mu \mathrm{g} / \mathrm{L}$ in surface water was recorded during the month of November 14' in station 1 and lowest value of $65.24 \mu \mathrm{g} / \mathrm{L}$ was recorded in station 3 during the month of May 15'. The highest value of $312.54 \mu \mathrm{g} / \mathrm{L}$ was recorded in bottom water during the month of November 14' in station 1 and lowest value of $60.24 \mu \mathrm{g} / \mathrm{L}$ was recorded in bottom water in station 3 during the month of May 15' (Fig .3). In the present study station 1 showed the highest value of iron content in both water. This area is located in ash dumpsite of thermal power plant. Normally Indian fly ash contains $2.5-9.0 \%$ of iron content. Lokeshappa et al., [9] reported that the iron content in ash in the form of $\mathrm{Fe}_{2} \mathrm{O}_{3}$ is $5.50-10.64 \%$ in Indian fly ash. The impact of ash in station 1 could be explained by the leaching behavior of iron in ash. Station 1 water sample showed the maximum value of $345.2 \mu \mathrm{g} / \mathrm{L}$ in the monsoon season. During monsoon, the dilution factor (df) of all the sampling stations in the coastal and estuarine zone of West Bengal increased manifold which results in the decrease of salinity and $\mathrm{pH}$. The lowering of $\mathrm{pH}$ might facilitate the dissolution of the precipitated form of metals and increase the amount of metallic ions in solutions [10] [11].

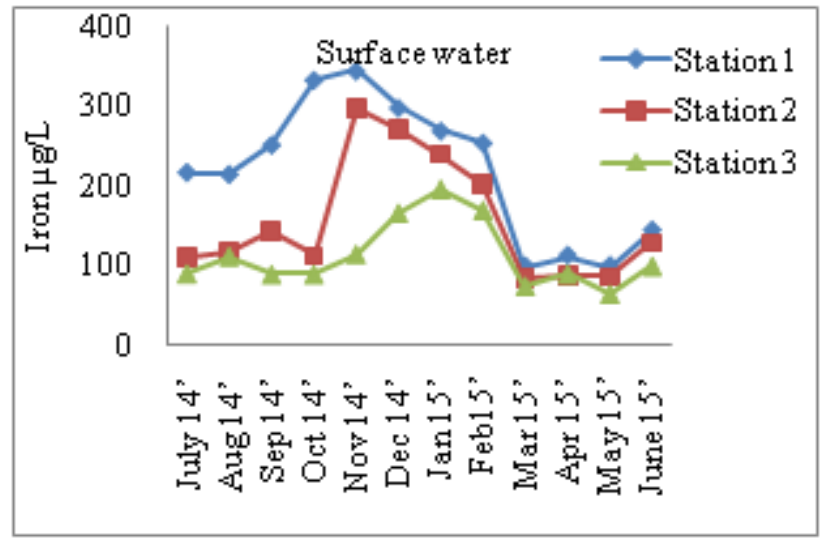

Figure 2: Monthly variations of Iron in surface water

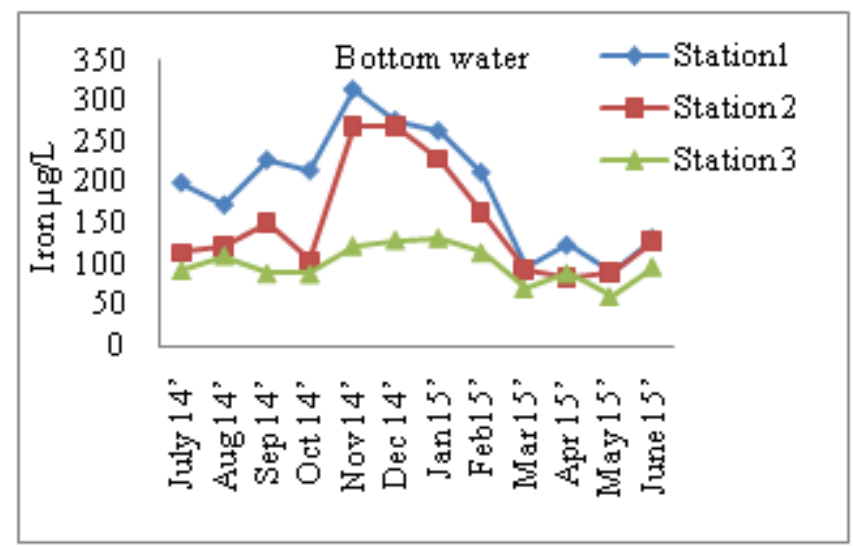

Figure 3: Monthly variations of Iron in bottom water

\subsection{Copper}

The mean value of copper ranged from below detectable level to $69.74 \pm 31.12 \mu \mathrm{g} / \mathrm{L}$. The highest value was recorded in station 1 (Table .1). The highest value of $120.5 \mu \mathrm{g} / \mathrm{L}$ was recorded in surface water during the month of December 14' and the lowest value was below detectable level (Fig .4) The highest value of $119.3 \mu \mathrm{g} / \mathrm{L}$ was recorded in bottom water during the month of December 14' and lowest value was below detectable level (Fig .5). The mobile fraction of $\mathrm{Cu}$ in environmental conditions has been estimated at $2.6 \%$ [12]. TCLP results yielded $0.5-3 \% \mathrm{Cu}$ extractable for alkaline fly ash [13]. In the present study station 1 , which is 


\section{International Journal of Science and Research (IJSR) \\ ISSN (Online): 2319-7064}

Index Copernicus Value (2013): 6.14 | Impact Factor (2015): 6.391

located near water outfall, showed higher value of copper $(39.7 \mu \mathrm{g} / \mathrm{g})$ content in water samples. From the above observation $1 \%$ of leaching occurs in alkaline fly ash. Present study also revealed the fly ash is alkaline in nature. Station 1 encountered high value of copper than the other two stations that showed the fly ash altered the copper content in water samples and the impact was reduced as the distance increased.

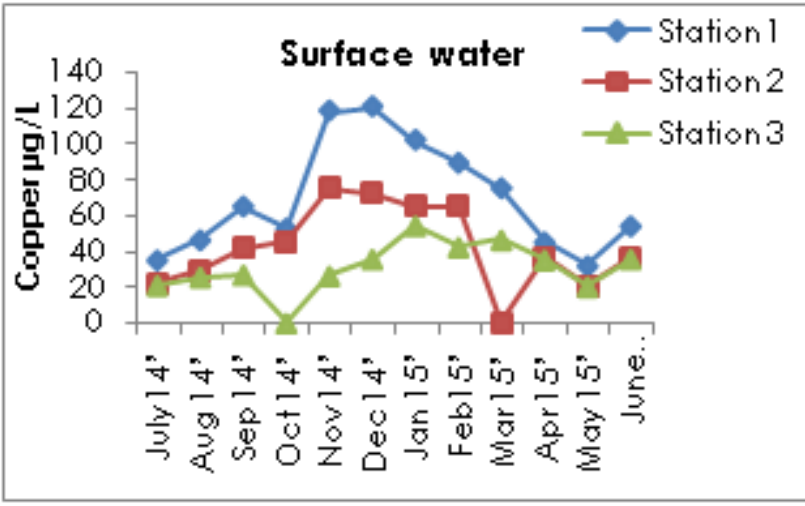

Figure 4: Monthly variations of Copper in surface water

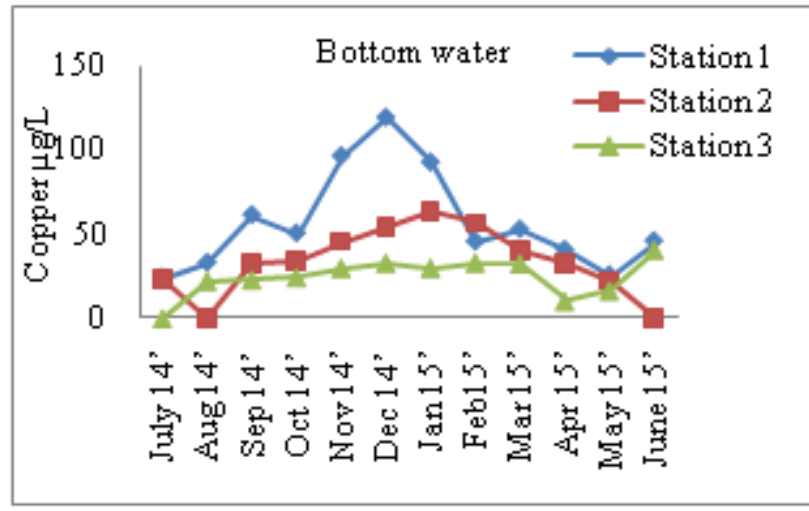

Figure 5: Monthly variations of Copper in bottom water

\subsection{Lead}

The mean value of lead in water sample ranged between below detectable level and $35.78 \pm 18.8 \mu \mathrm{g} / \mathrm{L}$. The maximum value was registered in station 1 (Table .1). In surface water the highest value of $36.5 \mu \mathrm{g} / \mathrm{L}$ was registered in station 1 during the month of December 14' and the lowest value was below detectable level (Fig .6). In bottom water, the highest value of $62.3 \mu \mathrm{g} / \mathrm{L}$ was registered in station 3 during the month of December 14' (Fig .7). Yogesh Kumar et al., [14] found high value of lead in Gulf of Mannar and reported that the various industries located in the main land which are closer to these island, may contribute to the high concentration of lead into these sites. Lead is recognized as a snowballing toxin in the metabolic activities of living beings. Lead level in the coastal environment is influenced by man-made activities [15].

Prasad and Mondal [16] observed the lead content of 27.7 and $65.3 \mathrm{mg} / \mathrm{kg}$ in two Indian ashes and also investigated the leaching behavior. He revealed that the leaching behavior was low for lead. Tripathi et al., [17] reported the lead content of fly ash was $40.1 \mathrm{mg} / \mathrm{kg}$. Gupta and Sinha, [18] were reported the lead content of fly ash was $26.81 \mathrm{mg} / \mathrm{kg}$.
Station 1 showed the highest value of lead content in water was during monsoon period and revealed that ash from dumpsite altered the lead content in marine environment.

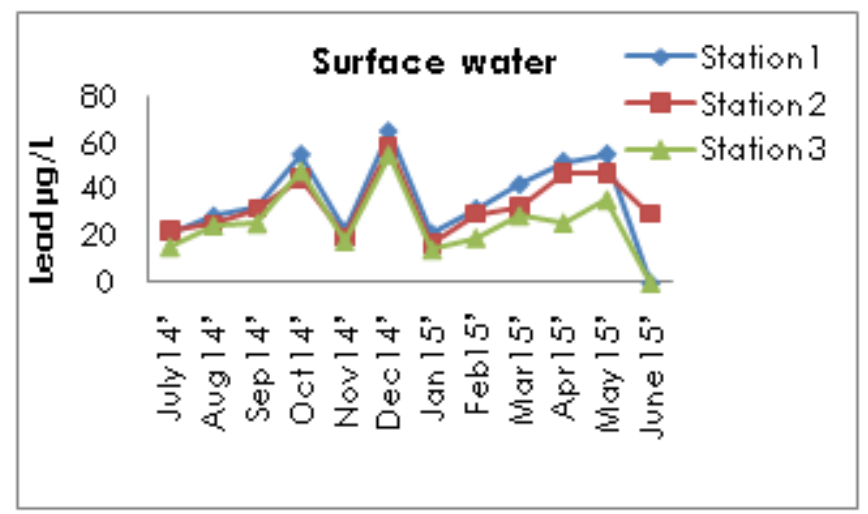

Figure 6: Monthly variations of Lead in surface water

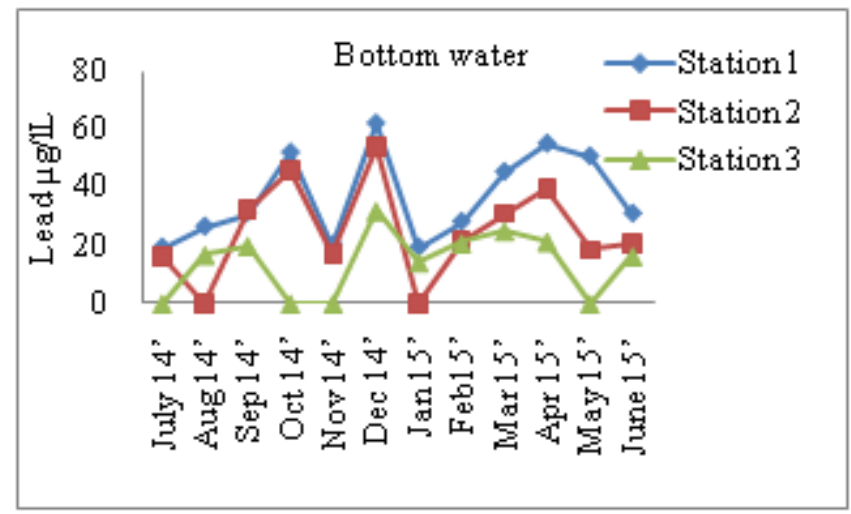

Figure 7: Monthly variations of Lead in bottom water

\subsection{Cadmium}

The mean value of cadmium in water sample ranged between $0.27 \pm 0.16$ and $0.4633 \pm 0.301 \mu \mathrm{g} / \mathrm{L}$. The maximum value was recorded in station 1 (Table .1) and minimum value was recorded in station 1 . The surface water showed the highest value of $1.02 \mu \mathrm{g} / \mathrm{L}$ in station 1 during the month of December 14' and the lowest value was below detectable level (Fig .8). The bottom water showed the highest value of $0.95 \mu \mathrm{g} / \mathrm{L}$ in station 1 during the month of December 14' and the lowest value was below detectable level (Fig .9). Cadmium is highly toxic to freshwater and marine organisms. It is bio accumulative through the food chain, also highly toxic to animals and carcinogenic to human beings [19]. Prasad and Mondal [16] showed leachability of cadmium in Indian ash. He compared two Indian ashes and reported that the cadmium concentration in both the leachates at all $\mathrm{pH}$. The ash dumpsite of station 1 showed maximum value of cadmium and the value decreased as the distance increasing from station 1 . 


\section{International Journal of Science and Research (IJSR) \\ ISSN (Online): 2319-7064}

Index Copernicus Value (2013): 6.14 | Impact Factor (2015): 6.391

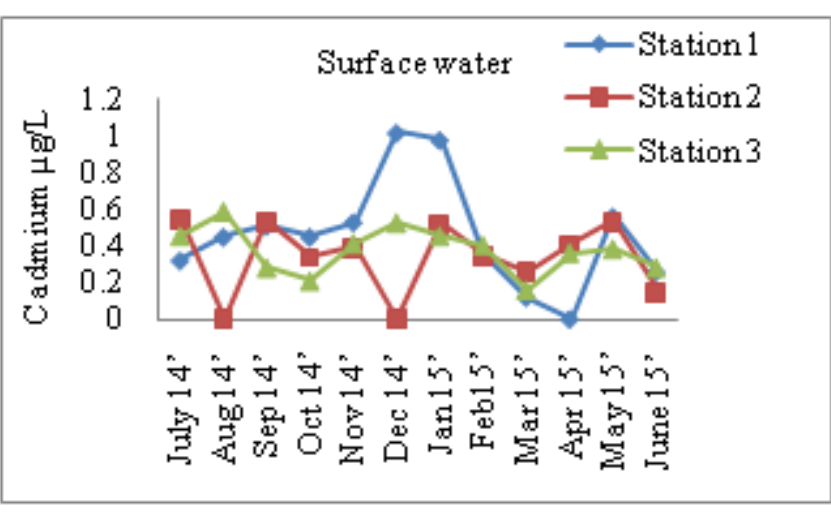

Figure 8: Monthly variations of Cadmium in surface water

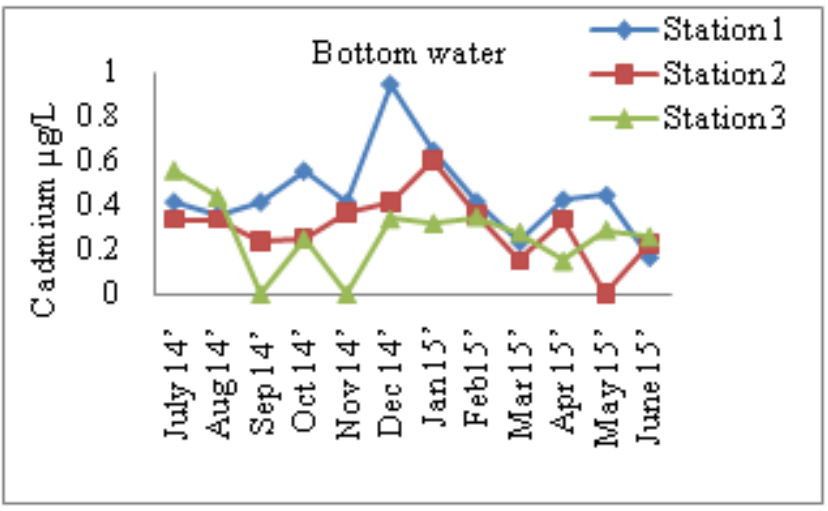

Figure 9: Monthly variations of Cadmium in bottom water

Table 1: Mean \pm SD of heavy metals in water

\begin{tabular}{|c|c|c|c|c|}
\hline $\begin{array}{c}\text { Element } \\
\mu \mathrm{g} / \mathrm{L}\end{array}$ & Area & $S 1$ & $S 2$ & $S 3$ \\
\hline \multirow{2}{*}{$\mathrm{Fe}$} & $\mathrm{S}$ & $219.89 \pm 88.4$ & $157.98 \pm 76.0$ & $113.0 \pm 41.6$ \\
\cline { 2 - 5 } & $\mathrm{B}$ & $193.25 \pm 71.7$ & $152.52 \pm 67.8$ & $99.59 \pm 22.7$ \\
\hline \multirow{2}{*}{$\mathrm{Cu}$} & $\mathrm{S}$ & $69.74 \pm 31.12$ & $46.20 \pm 20.12$ & $34.37 \pm 11.0$ \\
\cline { 2 - 5 } & $\mathrm{B}$ & $57.02 \pm 30.22$ & $40.4 \pm 14.00$ & $26.63 \pm 8.55$ \\
\hline \multirow{2}{*}{$\mathrm{Pb}$} & $\mathrm{S}$ & $35.78 \pm 18.83$ & $33.77 \pm 12.93$ & $25.86 \pm 14.9$ \\
\cline { 2 - 5 } & $\mathrm{B}$ & $36.84 \pm 15.47$ & $24.92 \pm 16.73$ & $13.92 \pm 11.2$ \\
\hline \multirow{2}{*}{$\mathrm{Cd}$} & $\mathrm{S}$ & $0.4633 \pm 0.30$ & $0.3358 \pm 0.19$ & $0.3733 \pm 0.1$ \\
\cline { 2 - 5 } & $\mathrm{B}$ & $0.4575 \pm 0.19$ & $0.3041 \pm 0.14$ & $0.27 \pm 0.161$ \\
\hline
\end{tabular}

S-Surface B- Bottom S1-Station 1 S2-Station 2 S3-Station 3

\section{Statistical Analysis}

Pearson Correlation coefficients between heavy metals of sediment within stations were analyzed [20]. The results are presented in table 2-7. The highly positive correlation was observed between iron and copper in station 2 surface water.

Table 2: Pearson product correlation at the surface water of heavy metals in station 1

\begin{tabular}{|c|c|c|c|c|}
\hline & Iron & Copper & Lead & Cadmium \\
\hline Iron & 1 & & & \\
\hline Copper & $0.599^{*}$ & 1 & & \\
\hline Lead & -0.226 & -0.097 & 1 & \\
\hline Cadmium & 0.488 & 0.549 & 0.212 & 1 \\
\hline
\end{tabular}

$*$ Correlation is significant at the 0.05 level (2-tailed).
Table 3: Pearson product correlation at the bottom water of heavy metals in station 1

\begin{tabular}{|c|c|c|c|c|}
\hline & Iron & Copper & Lead & Cadmium \\
\hline Iron & 1 & & & \\
\hline Copper & $0.750^{* *}$ & 1 & & \\
\hline Lead & -0.346 & 0.077 & 1 & \\
\hline Cadmium & $0.588^{* *}$ & $0.668^{*}$ & 0.376 & 1 \\
\hline
\end{tabular}

**Correlation is significant at the 0.01 level (2-tailed).

* Correlation is significant at the 0.05 level (2-tailed).

Table 4: Pearson product correlation at the surface water of heavy metals in station 2

\begin{tabular}{|c|c|c|c|c|}
\hline & Iron & Copper & Lead & Cadmium \\
\hline Iron & 1 & & & \\
\hline Copper & $0.930^{* *}$ & 1 & & \\
\hline Lead & -0.191 & -0.066 & 1 & \\
\hline Cadmium & 0.091 & -0.196 & -0.093 & 1 \\
\hline
\end{tabular}

Table 5: Pearson product correlation at the bottom water of heavy metals in station 2

\begin{tabular}{|c|c|c|c|c|}
\hline & Iron & Copper & Lead & Cadmium \\
\hline Iron & 1 & & & \\
\hline Copper & $0.728^{*}$ & 1 & & \\
\hline Lead & 0.140 & 0.293 & 1 & \\
\hline Cadmium & $0.636^{*}$ & 0.659 & 0.093 & 1 \\
\hline
\end{tabular}

* Correlation is significant at the 0.05 level (2-tailed).

Table 6: Pearson product correlation at the surface water of heavy metals in station 3

\begin{tabular}{|c|c|c|c|c|}
\hline & Iron & Copper & Lead & Cadmium \\
\hline Iron & 1 & & & \\
\hline Copper & 0.462 & 1 & & \\
\hline Lead & -0.122 & -0.051 & 1 & \\
\hline Cadmium & 0.516 & -0.465 & -0.153 & 1 \\
\hline
\end{tabular}

Table 7: Pearson product correlation at the bottom water of heavy metals in station 3

\begin{tabular}{|c|c|c|c|c|}
\hline & Iron & Copper & Lead & Cadmium \\
\hline Iron & 1 & & & \\
\hline Copper & 0.413 & 1 & & \\
\hline Lead & -0.041 & 0.066 & 1 & \\
\hline Cadmium & 0.247 & 0.332 & -0.077 & 1 \\
\hline
\end{tabular}

\section{Conclusion}

The study on the impact of fly ash in marine environment in Tuticorin bay provides a considerable insight into the quality of sea water in coastal area. The sea water quality is related to the health of environment. Assessment of sea water is a critical factor for assessment of pollution levels. The results from the present study pointed out that water from station 1 was comparatively contaminated with high level of trace metals. The results of heavy metals in water revealed that iron gets leached to some extent from the fly ash and increased the iron content in water. Based on this investigation, we concluded that this location is highly vulnerable and the impact is reduced as the distance increase from station 1 to station 3 . The gradual rises in heavy metal levels in the sea creatures have the chance to enter human life through the food web. Great attention should be given along the coastal region in order to control the

\section{Volume 5 Issue 6, June 2016 www.ijsr.net}




\section{International Journal of Science and Research (IJSR) \\ ISSN (Online): 2319-7064}

Index Copernicus Value (2013): 6.14 | Impact Factor (2015): 6.391

anthropogenic sources. It requires further investigation to monitor the contamination levels periodically.

\section{Acknowledgement}

The authors are thankful to Suganthi Devadason Marine Research Institute (SDMRI), Tuticorin for providing lab facility and support.

\section{References}

[1] Ali et al., 2013 Z. Ali, R.N. Malik, Abdul Qadir Heavy metals distribution and risk assessment in soils affected by tannery effluents Chem. Ecol., 29 (2013), pp. 676692

[2] Zhang et al., 2009 Y. Zhang, F. Guo, W. Meng, X.-Q. Wang Water quality assessment and source identification of Daliao River basin using multivariate statistical methods Environ. Monit. Assess., 152 (2009), pp. 105-12

[3] Lokeshappa, B., Dikshit, A.K., Giammar, D.E., Luo, Y., and Catalano, J.G., 2010. Metals in Indian fly ash: a preliminary investigation, presented at the 3rd International Symposium on Global Energy Futures, Washington University, Saint Louis, USA, October 14.

[4] Lokeshappa, B., and Dikshit, A.K., 2011. Metals and their leachings in coal fly ash ponds, presented at the National Conference on Environmental Perspectives and Challenges for the 21st Century (EPC-2011), Andhra University, Visakhapatnam, 28-29.

[5] Noel J.D., Biswas P., and Giammar D.E., 2007. Evaluation of a sequential extraction process used for determining mercury binding mechanisms to coal combustion byproducts, J. Air and Waste Management Association., 57: 856-867.

[6] Ganesan, M., and Kannan, L., 1995. Iron and manganese concentrations in sea water, sediment and marine algae of Tuticorin coast, southeast coast of India. Indian J. Mar. Sci., 24: 236 - 237.

[7] Palanichamy, S., and Rajendran, A., 2000. Heavy metal concentrations in seawater and sediments of Gulf of Mannar and Palk Bay, Southeast coast of India. Indian J. Mar.Sci., 29: 116-119.

[8] Brooks, R.R., Presley, B.J., and Kaplan, I.R., 1967. APDC-MIBK extraction system for the determination of trace metals in saline waters by atomic adsorption spectroscopy. Talanta, 14: 809-816.

[9] Lokeshappa B., and Dikshit, A.K., 2012. Fate of Metals in Coal Fly Ash Ponds. Intl. J. Environmental Science and Development., 3(1).

[10] Mitra A., 1998. Status of coastal pollution in west Bengal with special reference to heavy metals, India. J. Indian Ocean Stud., 5: 153-138.

[11] Bansal, O.P., 1998. Heavy meatl pollution of soil and ponds due to sewage irrigation, Indian J, Environ., Health., 40: 51-57.

[12] Soco, E., Kalembkiewicz, J., 2007. Investigations of sequential leaching behaviour of $\mathrm{Cu}$ and $\mathrm{Zn}$ from coal fly ash and their mobility in environmental conditions. J. Hazardous Materials., 14: 482-487.

[13] Ward, C.R., French, D., and Jankowski, J., 2003. Comparative evaluation of leachability test methods and element mobility for selected Australian fly ash samples. Cooperative Research Centre for Coal in Sustainable Development. Technical Note., 22.

[14] Yogesh Kumar, J.S.., and Geetha, S., 2012. Seasonal changes of hydrographic properties in sea water of coral reef islands, Gulf of Mannar, India. Int. J. Plant, Animal. Environl. Sci., 2(2): 135-157.

[15] Fernandez, C., Monna, F., Labanowski, J., Loubet, M., and Van Oort F., 2008. Anthropogenic lead distribution in soils underarable land and permanent grassland estimated by $\mathrm{Pb}$ isotopic compositions. Environ. Pollut., 156: 1083-1091.

[16] Prasad, B., and Mondal, K.K., 2008. Heavy metals leaching in Indian fly ash. J.Environ.Science \& Engg., 50(2): 127-132.

[17] Tripathi R.D., Vajpayee P., Singh N., Rai U.N., Kumar A., Ali M.B., Kumar B., and Yunus M. 2004. Efficacy of various amend-ments for amelioration of fly ash toxicity: growth per-formance and metal composition of Cassia siameaLamk. Chemosphere, 54:1581-1588.

[18] Gupta, A.K., and Sinha, S., 2008. Decontamination and/or revegetation of fly ash dykes through naturally growing plants. J. Hazard Mater., 153: 1078-1087.

[19] Palanichamy, S., and Rajendran, A., 2000. Heavy metal concentrations in seawater and sediments of Gulf of Mannar and Palk Bay, Southeast coast of India. Indian J. Mar.Sci., 29: 116-11.

[20] Sokal, R.R., and Rohlf, F.J., 1987. Introduction to Biostatistics. Second Edition. New York. W.H. Freeman and Company., pp. 363. 